\title{
SHARING ECONOMY: \\ EVALUATING ITS STRUCTURAL DIMENSIONS FOR POLICY DESIGN PURPOSES
}

\author{
Dr. Oana ALBESCU \\ oanaalbescu@yahoo.com
}

Dr. Mircea MANIU

Associate Professor, Babeș-Bolyai University

$\underline{\text { mircea.maniu@ubbcluj.ro }}$

\begin{abstract}
:
The current rising in economic polarization maintains an elevate interest for the social and ethical dimensions of the economy. As such, the new modes of wealth creation and redistribution derived from the digital revolution impose themselves as important premises and solutions to old and persistent economic and ethical problems. Sharing economy is a new concept covering recent structural changes of the contemporary economy resulting from the spread of new digital technologies. In order to reach a better understanding of the process of conveying towards such a type of economy we have conveniently distinguished four dimensions of the phenomenon. First of all we classify the economic nature of sharing economy. Following this we try to explain the technology conditions rendering it possible. Thirdly, we confront the controversial present day ethical aspects of the topic and last but not least, we attempt to elaborate on the issues surrounding the emergence of such a comprehensive potential new development model in view of a researchbased policy assessment. As such, we have interrogated the academic debate over the sharing economy which is reflected in the controversy surrounding the regulation policy of these atypical economic relations. Though we endeavor to investigate as much as possible the endogenous, Romanian perspective of the topic, in all the above mentioned layers, it is precisely this fourth dimension of our research that gives it a domestic consistency.
\end{abstract}

Keywords: sharing economy, non-standard new economy, economic ethics, social economy, policy design 
Issue no. $22 / 2017$

\section{Preamble}

The contemporary dynamics of producing commodities or services, generating revenues and wealth, associated with the historical output series of the XIXth and XXth centuries, show somehow paradoxically a return to the symptoms of early capitalism's assets polarization, along with the gradual increase in the degree of fuzziness of the welfare economy, at least as assessed in the parameters that were valid for most of the XXth century. As Thomas Piketty exemplifies in his consistent Capital in the Twenty First Century, less than $10 \%$ of the population of North America and Europe own today more than half of the existing capital (Piketty, 2015).

As we move towards a post-industrial, or ,second machine age” (Brynjolfsson and McAffee, 2016), the inequality tends to spread to the very process of work, reshaping first of all the labor market, in line with the new technological parameters. It is precisely within this juncture that notions, concepts or simply put labels such as "sharing economy", "peerto-peer" or "open-source" depict the new patterns of production, wealth creation and redistribution (Mayer, 2014). It is beyond doubt that such an approach, eventually patterned, would be consistent with the present day world economy welfare thresholds, especially with those reflecting the EU social economy.

To a certain extent the traditional EU benchmarks of social equity are directly jeopardized by the cumulative effects of the new wave of technology that generates completely unexpected levels of capital efficiency in peculiar areas and the speedy quest for European competitiveness within a more and more challenging world economic environment. Giacomo Corneo underlines that the process of "democratization" of capitalism through extended ownership could be a pragmatic answer (Corneo, 2014). The contemporary role of the public capital is under constant re-assessment today, but plenty of rational arguments emerging from the traditionally assessed inefficiency of the public sector throughout the world plead for the necessity of investigating more lucrative paths. Consequently sharing economy (SE) appears to us as a valid short and medium term 
option, encapsulating economic and extra economic resilience features that could turn it into the comprehensive model of the near future.

\section{The economic perspective}

The last years witnessed an increasing form of a new approach to economy that is significantly more aware of ethical concerns of the economic process than the classical business model. This has been designated as SE. Some authors, relevant within the context, reveal in their studies that $\mathrm{SE}$ is a new economic phenomenon that is gradually changing the rules of the game, taking in this way by storm the media, social network and eventually the public discourse. SE is seen as an alternative form of consumption based on collaboration in the production, creation or use of products and services. SE simplifies and redefines collaboration by the means of technological advances and online communication, making people able to share, barter, lend, rent, swap and gift their property in a much easier manner (Kreiczer-Levy, 2015).

There are varying opinions that highlight the lack of scientific publications on the topic and confine its definition to companies that deploy accessibility based business models for peer-to-peer markets and its users (European Commission, 2013a). Arun Sundararajan (2016a), an established authority on the topic, defines SE along five fundamental features:

a) it is a free-market phenomenon;

b) it is based on putting underutilized (potential) capital to use;

c) it develops on "crowd-based networks" such as online platforms;

d) it overcomes traditional frontiers between the personal and the professional;

e) blurs the lines between (full-time) employment and casual work.

He does not consider SE as a departure from capitalism to some type of socialism, but, more accurately as a departure from "corporate-centered capitalism" towards "crowdbased capitalism" or, as such, an intermediate form between capitalism and socialism 
(Sundararajan, 2016b). Businesses such as Airbnb, Lyft, Uber, Taskrabbit are actually empowering consumers over major transport, service or hotel corporations. In this sense it is a triumph of small actors on the market over great established actors not able to compete efficiently.

In a first attempt to adapt the regulatory framework to emerging forms of SE or "collaborative economy", the European Union has delineated a series of principles and policy recommendations, with the purpose of encouraging the development of new and innovative services and also with the purpose of ensuring adequate consumer and social protection. A very important aspect to be mentioned is that the SE can contribute to the EU's sustainability agenda and to the transition to the circular economy. In the European Agenda for the collaborative economy, we find a very coherent and articulate characterization in terms of business models where activities are facilitated by collaborative platforms that create an open marketplace for the temporary usage of goods or services often provided by private individuals. This agenda also describes three categories of actors that participate to the collaborative economy, namely: 1. the service providers who share assets, resources, time and skills, 2. the users of these and 3. the intermediaries that connect, via an online platform, providers with users (European Commission, 2016).

In our opinion, the new trend we designate as SE is somewhat contradictory since sharing implies giving (for others), whereas economizing implies saving (for oneself). This paradoxical nature of SE notwithstanding, it seems that many new business ventures based on a broader notion of the economic incentive than the traditional profit-seeking do work very well precisely because they insist on closer relationships and trust-building. This is grounded of the increased awareness that social capital is more than financial capital, and that enduring investment require the inclusion and increasing of social capital as well.

SE is not of course entirely replacing traditional business models. SE includes the profit incentive in most of cases. Only it does so in a broader, non-exclusive and more 
sensitive way. SE is therefore a non-standard new economy complementing classical styles of business. Some of the sharing models came about as "austerity" reinvention of consumption patterns during the financial crisis. This implied a different approach to consumption goods (be it an apartment or a car). Goods needed to be shared in order to reduce consumption and recover losses. Nevertheless, this has met a real demand on the market, namely people doing the same thing. The result was very rational - satisfying the same demand with a lower supply. As such, SE appears economically rational, although it seems more emotional at the first glance.

\section{The technology perspective}

If we were to determine one single factor responsible for the flourishing of SE modalities, this would be the digital revolution and its most recent consequences. It has been already remarked that many jobs that were performed by people are now performed by software. In this sense, technology saves resources while performing better. The one technical device that has made SE successful was definitely Steve Jobs' iPod (Thierer, 2014). This device has created new opportunities for very old feelings, inclinations or moral desires that the classical market was not able to meet satisfactorily. But it is only in this current age where new digital technologies have revolutionized people's ability to exchange economically, socially and morally relevant information, that a critical mass has been attained.

Digital technologies are more able on the one side to concentrate information, on the other side to focus information about those who can share and those who need to receive. They have achieved the ability to check and process the most information and in the most individualized and precise manner. On a larger scale the task is to permanently and clearly identify those who need to receive the surplus and those who actually possess a certain surplus. Internet renders the synchronization of givers and takers plausible. With the advent of internet, the flow of information, the availability of economically (and 
morally) relevant information is quite outstanding. Sometimes this is one click-away. Of course, meeting supply and demand are age-old problems of economy.

In the new light of SE this problem takes the new shape of trying to make meet people who are socially or morally dedicated to a slightly different economical behavior than the classical one. Not everybody will join the SE, which is more likely to remain a sub-system of the market. Still, new ventures, new platforms are already in place where people sharing the same interest in combining individual gain and social contribution, or where business oriented entrepreneurship with meets with social entrepreneurship and exchange values on permanent basis (Praszkier and Nowak, 2012).

We can skeptically ask how much are people ready to contribute. Would they share if it was more difficult? Would they share if it was more personally expensive? This varies of course with the case. Certain is that internet and smart phone apps have made "affordable" new modalities of sharing, modalities that were too difficult to perform before.

Let's take an example: giving someone a lift if meeting operatively, but not being able to wait an unspecified amount of time in order to help somebody. Synchronization is therefore time-saving and decisive. And this is why the internet revolution has created huge new possibilities that simply did not existed before, in the sense that they were too costly and impracticable before. Technically, this has also been possible with the appearance of block chain technologies, able to assure online secure transactions, through a growing database that is modification-resistant so that transactions cannot be altered once they are performed. It is technology that extends the traditional frontiers of trust through the "digitization of trust", allowing reputational capital to be validated and increased through peer-to-peer open evaluations and transparent transaction procedures.

We can strongly reiterate that the conventional business model is subject to change. A EU Commission's report delineates two trends in the evolution of the SE. Briefly we can first describe the technological advancement that allows the business model to spread to 
more and more markets and thus become more convenient and flexible. One example is the car rental company "Car2Go", which provides members with flexible and nearby access to individual mobility through a large quantity of rental cars that are distributed across European cities. The second trend we want to draw attention at constitutes a shift to peerto-peer accessibility based business models. In peer-to-peer models, companies are facilitating access for consumers to consumer owned property or skills and competencies. An online platform connects consumers that own certain assets and skills with consumers in temporarily need of those (European Commission, 2013b).

In the dedicated literature, there is a widely held belief that computers and the Internet made it possible to exchange works on a much larger scale, without depriving the original owner of access to them. Furthermore, digital technology and the Internet gave us important resources, such as new media, each bringing new types of creative work or a new world of cultural practices which do away with the clear-cut distinction between producers and consumers (Agrain, 2012). Moreover, present day EU is actually the best ground for evaluating the global scale switch from multicultural to intercultural features that illustrate the very essence of the contemporary technological revolution (Dan, 2014).

\section{The ethical perspective}

Sharing in itself is of course an all-time moral inclination that has been preached by ethical idealism in almost all religions. The correlation sharing and receiving is a couple of notions that parallels the supply and demand categories. This is an ethical correspondent of the economical world. Sharing means being able to give away, that is to detach oneself form a rigid notion of ownership.

Entrepreneurs are people who are seeking to make a profit by identifying a social need (or demand) and trying to come up with a product designed to address this demand (or supply). Social entrepreneurs are people who (at least in theory) are building a business designed to help people, to advance availability of good, or to reduce waste. Otherwise put 
Issue no. 22/2017

- to somehow make a contribution but without placing the profit-incentive at the core of their business. As such, SE includes economic activities that are socially or ethically aware as well.

Walter Vassallo's approach draws attention in this context. The author defines trust as the essential ingredient for economic and social relations and, more interesting, as the substratum of the SE and co-creation. The author further explains that trust is at the roots of the European economic system and, in the emerging SE, trustful relations are a prerequisite (Vassallo, 2017). Previous generations would have never allowed strangers into their cars of apartments. Trust has become however easier in the digital economy. Trust is based on accurate and reliable networks where data are held and so strangers are not so strangers anymore. Peer-to-peer review of transactions render people more responsible since the old market saying "You're only as good as your reputation" is very much alive (Botsman, 2012).

In order to understand the manifold dimensions of this new sharing movement from the standpoint of its ethical dimensions we try to classify different behavior falling under this notion:

a) Charity economy. Charity is the disinterested sharing of goods for people in need. This ethical virtue is, of course, implicit social economy. Even though it is a moral commitment, it also makes a difference in economic terms since it changes the owner of goods. As such, the most disinterested forms of SE are a subdivision of charity (which is a spiritual and ethical virtue).

b) Communitarian economy. An interesting aspect is that people who take part in SE are people who do not want to reduce exchange to mere impersonal processes. Meeting people, creating local networks or even friend circles bring about moral experiences. At least as important as owning and consuming is the feeling that the economic community is also a moral community. As such, SE brings about the enlivening the economic process 
which are not anonymous anymore. This renders the economic process more personal, instead of alienating, and it seems that SE also reflects emotional choices of people.

c) Austere economy. Exchanging instead of buying is also a significant part of the SE. Setting aside short-time gain this ethical dimension of consumption has rational as well as emotional gains. This avoids waste and encourages recycling, but in a wider sense that garbage recycling. On a long-term, this saves resources and brings people a relative fulfillment. As such, SE is a subdivision of the wider notion sustainable economy - not totally disinterested, but dedicated to saving resources, to minimizing loss and consumption abuse. The good thing about this kind of self-imposed "austerity" practices is that they are personal and voluntary and they combine economic profitability with sustainability.

The socio-economic relevance of the SE is remarkable. In the context of decreased consumer trust in the corporate world as a consequence of the economic crisis, consumers have become more receptive to peer-to-peer business models which promote the consumer needs, both as a supplier and buyer. How can the company help build the SE? Take for instance the business innovation brought by the a company such Airbnb, hosting an online platform through which peers can list, discover and book unique places, all made available by other peers. This has been described as the most widely spread method for people to monetize their extra space and showcase it to an audience of millions (European Commission, 2013c). This example is thought to be the most prominent example of a huge new "SE" in which people rent beds, cars, boats and other assets directly from each other, coordinated via the internet (Economist, 2013).

Blablacar another example of the kind, arranges to give people a ride and it is always cheaper than mainstream transportation. As such, overcrowding and oil consumption is reduced. Lower costs come with reduced waste and pollution. There are also more difficult problems to solve. For example food sharing makes a case against food waste in a challenging environment. Some online platforms try to solve this situation and 
excess food is donated, so other people can take advantage of it (i.e. foodsharing.de). The real difficulty is not to convince people not to throw food away, but to make it easy to synchronize demand and supply, to bring food which alters rapidly to those in need of it.

We have noticed an interesting ad-hoc local solution to this challenge. At Iulius Mall (a commercial mall in Cluj-Napoca, our hometown), after restaurants are closed, a spontaneous arrangement came about, with homeless or needy people standing in line at the back door, approach which actually make excess food (leftovers), meet with demand. We take this as a good example combining classical economy and non-standard SE.

\section{The policy perspective}

The spontaneous emergence and arrangement of SE has social, economical and ecological consequences as well. As a new phenomenon, SE does not yet have too many political (top-to-bottom) dimensions. For example, literature indicates that in San Francisco there is a functional SE that has spontaneously emerged. In Seoul, on the other hand, it is the authorities who try to enforce it by imitation in order to deal with social problems residual of the economic crisis. These cases are very different. Most of the calls for a government regulation of the SE result of a criticism of free-market difficulty of assuring consumer protection. As in many economic cases, we are facing anew the old dilemma of market self-regulation versus government regulation. Critics argue that, before the market can clear-up itself there will be many "collateral damages", so that government should already consider putting regulation in place.

This resonates with the debate pro and against SE. Policy design should come as an outcome of the manner in which we settle the case between the two different approaches concerning SE. We would illustrate this controversy by briefly comparing two established authors holding opposing views on the benefits of SE. In order to solve problems, the already mentioned author Arun Sundararajan favors increased peer-to-peer marketplace regulation. Where this fails, new self-regulatory bodies (such as customers associations, 
professional organizations) should double the market intrinsic regulation with a sort of professional and moral supervision. He views "crowd-based capitalism" as a more refined version of Adam Smith's invisible hand, able to synchronize supply and demand in a more efficient and faster way, as well as in a more detailed fashion that was conceivable before the digital revolution.

Other authors indicate the growing insecurity for workers or externalities for other parties (neighbors, communities). Tom Slee is concerned that through SE, capitalism has invaded areas traditionally protected, such as the private life. He believes vulnerable people are actually more facing more risks. People active in the SE are seldom full-time entrepreneurs - most of them are only gaining extra-money. Following the success of the first corporations mediating services on the market, such as Airbnb or Uber, he observes that they have since grown into big corporations. On the one hand Uber empowers customers or free-lance entrepreneurs but on the other side it fights local taxi drivers. This author argues that the idyllic notion of someone sharing his apartment with you is already overshadowed by entire-flats virtually used as hotels, competing therefore long-term rentals (leading to fewer apartments available for long-term rental). Flat-sharing has evolved into hotel-service, just as well as ride-sharing has grown into taxi-service. The risk is greater since the intermediate corporation declines responsibility and accountability is difficult to establish and enact. People in this industry are not classical employees so that they are not covered by social security. He also argues that the reputational assessment of customers and services (by means of reviews) does not work as ideally as presumed and since then, a more rigid supervision has already been introduced (Slee, 2015).

The permanent litigation Uber confronts across the world illustrate how these controversial aspects have inspired some to establishing of greater organisms to administer and optimize the distribution of resources, to generalize the SE - which would amount to control and supervision by superior authorities. This is of course itself problematic - since the very success of these start ups came from their decentralized and independent structure, 
from their free decision to cooperate, each within the field where they possessed the required knowledge. An institutional supervision would entail state bureaucratic control that would most likely face problems that the local enterprises do not have. Who should regulate SE and how exactly is therefore controversial.

A recent European Parliament report shows that the SE is affected by an equally wide range of EU policy regarding two relevant areas. Firstly, we should mention policy which affects SE platforms such as digital services, and, secondly, policy which affects SE services, through their effects on the general regulation of the services which are provided through those platforms. It is worth mentioning that despite the considerable existing volume of policy applicable to the SE significant issues remain that require consideration. We can mention but a few: achieving regulatory objectives at higher cost than necessary, market segmentation and restriction, not making use of platform data, or the fact that the SE has the potential to encompass a significant portion of economic and social life which might create a danger of a new form of social exclusion (European Parliament, 2016).

It appears that the investment on social infrastructures within the framework of EFSI is lower than expected - most certainly a consequence of austerity measures. The question still remains whether decrease in microfinance or social entrepreneurs' investment does not reinforce economic stagnation. In this context, it is interesting to analyze some affirmations that want to open the path to the recovery of social Europe. Jean-Claude Juncker stated that "Europe is not social enough. We must change that" (European Commission, 2017a). The change will take the form of the European Pillar of Social Rights, the necessary instrument to ensure fairness and social justice in Europe. Other EU officials, for example the Commissioner for Internal Market, Industry, Entrepreneurship and SMEs, strongly believe that the collaborative economy or the SE is an opportunity for consumers, entrepreneurs and businesses and, with the help of proper management, SE could create additional jobs and growth (European Commission, 2015). 
Issue no. 22/2017

\section{Focus: SE in nowadays Romania}

Along with EU membership came various exogenous leverage mechanisms that pushed ahead the welfare state throughout Central and Eastern Europe, contrasting with the ideologically patterned models previously in place (Fuchs and Offe, 2009). Our country would be no exception to the rule, but one should acknowledge that the pace of evolution towards the average EU benchmarks in this respect is definitely not satisfactory. As the very recent Reflection Paper on the Social Dimension of Europe (European Commission, 2017b) points, Romania is lagging behind many European countries on several social layers.

Indeed, 2017 Romania provides a strongly relevant unsound economic example, namely of the public sector benefiting of an average double salary as the private sector, while productivity would be comparable. In any decent framework of economic policy this sends us a truly worrying signal about the imperative of reshaping the system in order to cope with the various challenges of today. But setting aside government-related problems, Romania has experienced continuous growth since fully recovering from crisis in 2012. It currently strives to evolve from an emergent market to a mature market, with all the entrepreneurial features that are necessary for sustainable development, including incipient forms of social entrepreneurship, as we found in a previous research (Albescu and Maniu, 2015).

As we already underlined the crisis was an incentive to innovation and new business models packed with information technology were encouraged. This explains the rapid synchronization with European flows and trends, especially a very dynamic IT sector. Major players in the SE have recently invested on the Romanian market. Uber and Airbnb, the two SE pioneers faced a very controversial reaction. The local market has not only spontaneously adapted but it also created similar reactions. The same litigation between new global famous SE services and traditional competing industries has already been observed in this country too. Uber has been repeatedly involved in incidents with 
local taxi companies in Bucharest or Cluj-Napoca. A taxi license is very hard to get and this makes the taxi-market an oligopoly. Taxi companies, on the other side, feel mistreated that they have complied with the licensing procedure while their competitor did not. But there are also new successful local companies in the realm of SE, start-ups that have adapted to the new technologies that have since emerged - we will mention only two of them, namely Pony Car Sharing and Sameday Courier.

As in many cases, the spontaneous success of SE has left the regulatory authorities behind. The EU has recommended member states not to prohibit these new services. But the effort to bring clarity into this matches the novelty of the technology. What stands for example in debate is whether an Uber driver is an employee or an entrepreneur himself. This has important consequences in social security and fiscal policy alike. Recently, the Romania Parliament's Commission for Information Technology and Communication has released for public debate a law project designed to regulate the emerging market (Camera Deputaţilor, 2015). The public debate barely started, and all interested parties are called to contribute, since the EU recommendations are still too general. The lawyer and publicist Bogdan Manolea has critically commented this draft:

"The principle put into practice by the Law 365/2002 in Romania and by the Ecommerce directive in Europe is relatively simple: online services (also designated as services of the informational society) require no preliminary authorization. Nowadays this seems even more reasonable than in 2000 when it was less clear: how would it have been for someone who wanted to create and website of any kind to pass it through a commission of bureaucrats in order to get a license?" (Manolea, 2017a)

The author complains that the draft continues to remain a general statement of principles. It doesn't even answer the question why should this field be regulated in the first place. The law does not identify a specific problem caused by these industries that can only be solved through a law. Many obligations (such as data protection, information security of tax imposition are already regulated). New obligations that were suggested - 
such as the owner of the online platform should certify/document the authenticity of data registered on the platform are simply unrealistic (it is like demanding a journal to check the announcements they publish on the buy-and-sell list) - this should be left to those who engage in transactions. Despite the fact that the draft claims it supports the new field, it only imposes obligations and sanctions.

The author concludes: "so the question again is: do we want regulation, selfregulation or we simply want them to leave? For now, judging from this draft of law it would appear that we simply want them all to leave and we want to erect barriers for others like them in the future. Maybe a better solution would be to first identify the problems and to debate them. And if we want self-regulation or co-regulation, we would better first expose them to those concerned, from the industry, and to understand how they see them solved." (Manolea, 2017b)

To summarize our approach, it appears that the development of SE in Romania is primarily driven from the input of the global pioneers of the industry that have expanded into our domestic market. Secondly, there are several small local companies that have adapted and have grown steadily, which is an encouraging trend. And finally, the regulatory authorities are lagging behind the level of responsiveness showed by equivalent authorities elsewhere in EU. Though trying to make sense of the EU recommendation and to adapt old legal notions to new economic realities, Romanian lawmakers have still plenty to fare in order to allow SE the same kind of impetus as in more developed economies. But, we should acknowledge that today new and unexpected SE facets are emerging, while some already established ones are changing fast and all across the world, not only EU, and therefore it is a fact that their legal status and public regulation would be still to a large extent controversial. 
Issue no. $22 / 2017$

\section{References}

- AIGRAIN, P. (2012) Culture and the Economy in the Internet Age, Amsterdam University Press, pp.22-28

- AlBesCU, O., MANIU, M. (2015), "Convergence Theory Revisited: Social Entrepreneurship", in Mişcoiu, S. and Naumescu, V. (Eds.), What is left from the leftright cleavage? A comparative perspective, Bucharest, Editura ISPRI, pp. 207- 227

- BOTSMAN, R. (2012), The Currency of the New Economy Is Trust, TEDGLOBAL. Available from http://www.ted.com/talks/rachel_botsman_the_currency_of_the_new_economy_is_trus $\mathrm{t}$

- BRYNJOLFSSON, E., McAFFE, A. (2016), The Second Machine Age. Work, progress and Prosperity in Time of Brilliant Technologies, W.W. Norton and Co., New York

- CAMERA DEPUTAŢILOR (2015), Project-Law for the Economy of Access, Available from http://www.cdep.ro/pls/proiecte/upl_pck2015.proiect?idp=16140

- CORNEO, G. (2014), "Public Capital in the 21st Century", Friedrich Ebert Stiftung, SE Journal, Research Essay No. 2, pp. 3-5, Available from https://www.socialeurope.eu/wp-content/uploads/2014/11/RE2-Corneo.pdf

- DAN, H. (2014), “The Role of Interculturalism in European Integration”, in Studia Universitatis Babes-Bolyai. Studia Europaea, No. 2/2014, pp. 9-11

- ECONOMIST (2013), The rise of the Sharing Economy, March 9, Available from http://www.economist.com/news/leaders/21573104-internet-everything-hire-risesharing-economy

- EUROPEAN COMMISSION (2013a), Business Innovation Observatory, The Sharing Economy. Accessibility Based Business Models for Peer-to-Peer Markets. Case study 12, Available from http://www.eukn.eu/fileadmin/Lib/files/EUKN/2014/12-sheaccessibility-based-business-models-for-peer-to-peer-markets_en.pdf 
- EUROPEAN COMMISSION (2013b), Business Innovation Observatory, The Sharing Economy. Accessibility Based Business Models for Peer-to-Peer Markets. Case study 12, p.3, Available from http://www.eukn.eu/fileadmin/Lib/files/EUKN/2014/12-sheaccessibility-based-business-models-for-peer-to-peer-markets_en.pdf

- EUROPEAN COMMISSION (2013c), Business Innovation Observatory, The Sharing Economy. Accessibility Based Business Models for Peer-to-Peer Markets. Case study 12, pp. 4-5, Available from http://www.eukn.eu/fileadmin/Lib/files/EUKN/2014/12she-accessibility-based-business-models-for-peer-to-peer-markets_en.pdf

- EUROPEAN COMMISSION (2015), Daily News, Available from http://europa.eu/rapid/press-release_MEX-15-4706_en.htm

- EUROPEAN COMMISSION (2016), Communication from the Commission to the European Parliament, the Council, the European Economic and Social Committee and the Committee of the Regions. A European agenda for the collaborative economy, $\operatorname{COM}(2016), \quad$ Available from http://ec.europa.eu/growth/singlemarket/services/collaborative-economy_ro

- EUROPEAN COMMISSION (2017a), Towards a European Pillar of Social Rights, Available from https://ec.europa.eu/commission/priorities/deeper-and-fairer-economicand-monetary-union/towards-european-pillar-social-rights_en

- EUROPEAN COMMISSION (2017b), Reflection Paper on the Social Dimension of Europe, April 2017, Available at https://ec.europa.eu/commission/sites/betapolitical/files/reflection-paper-social-dimension-europe_en.pdf

- EUROPEAN PARLIAMENT (2016), The Cost of Non-Europe in the SE. Economic, Social and Legal Challenges and Opportunities, pp.23-26, Available from http://www.europarl.europa.eu/RegData/etudes/STUD/2016/558777/EPRS_STU(2016) 558777_EN.pdf 
- FUCHS, S., OFFE, C. (2009), "Welfare State Formation in the Enlarged European Union: Patterns of Postcommunist States", in The SAGE Handbook of European Studies, SAGE, London, pp. 420-441

- KREICZER-LEVY, S. (2015), "Consumption Property in the SE", in Pepperdine Law Review, Vol. 43:61, Available from http://pepperdinelawreview.com/wpcontent/uploads/2015/12/Kreiczer-Levy_Final-no-ICRs.pdf

- MANOLEA, B. (2017a), Cum se incearcă reglementarea Uber, Airbnb, Indiegogo și ce mai pică, Available from http://legi-internet.ro/blogs/index.php/cum-se-incearcareglementarea-uber

- MANOLEA, B. (2017b), Cum se incearcă reglementarea Uber, Airbnb, Indiegogo și ce mai pică, Available from http://legi-internet.ro/blogs/index.php/cum-se-incearcareglementarea-uber

- MAYER, H. (2014), "Inequality and Work in the Second Machine Age", Friedrich Ebert Stiftung, SE Journal, Research Essay No. 4, pp. 7-8., Available from https://www.socialeurope.eu/wp-content/uploads/2014/12/RE4-Meyer.pdf

- PIKETTY, T. (2015), Capitalul în secolul XXI, București: Editura Litera, 2015, pp. $556-557$

- PRASZKIER, R., NOWAK, A. (2012), Social entrepreneurship. Theory and practice, Cambridge University Press, Cambridge, pp. 22-23

- SLEE, T. (2015), What's Yours is Mine. Against the Sharing Economy, OR Books

- SUNDARARAJAN, A. (2016a), The Sharing Economy: the End of Employment and the Rise of Crowd-Based Capitalism, Cambridge - Massachusetts: MIT Press, pp. 5-20

- SUNDARARAJAN, A. (2016b), The Sharing Economy: the End of Employment and the Rise of Crowd-Based Capitalism, Cambridge - Massachusetts: MIT Press, pp. 4045 
- THIERER, A. (2014), Permissionless Innovation: The Continuing Case for Comprehensive Technological Freedom, Arlington, VA: Mercatus Center, p. 20

- VASSALlO, W. (2017), Crowdfunding for Sustainable Entrepreneurship and Innovation, USA: Business Science Reference, p. 25 